\title{
Simulasi Berbagai Situasi Traffic Flow Menggunakan Persamaan Kinematik dan Implementasi Metode Finite Volume
}

\author{
Yoreza Mandala Putra \#1, Putu Harry Gunawan \#2 \\ \# School of Computing, Telkom University \\ Jl. Telekomunikasi No. 1, Terusan Buah Batu, West Java, Indonesia, 40257 \\ 1 yorezamandala@student.telkomuniversity.ac.id \\ 2 phgunawan@telkomuniversity.ac.id
}

\begin{abstract}
This journal discusses traffic flow which is modeled by the kinematic Lightill, Whitman, dan Richard (LWR) equation. The numerical finite volume scheme is applied to solve the equation. The scheme is used to simulate two important conditions, namely: increasing length of the vehicle queue (shock wave), and the decay of vehicle density after the green light turn (rarefaction wave). Furthermore, the scheme is also used to simulate the increase in traffic density due to narrowing roads, or road blockade.
\end{abstract}

Keywords: Kinematic LWR equations, shock wave, rarefaction wave, finite volume method

\begin{abstract}
Abstrak
Jurnal ini membahas mengenai aliran lalu lintas yang dimodelkan dengan persamaan kinematik Lightill, Whitman, dan Richard (LWR). Skema numerik finite volume diterapkan untuk menyelesaikan persamaan tersebut. Skema ini digunakan untuk menyimulasikan dua kondisi penting, yaitu: bertambahnya panjang antrian kendaraan (shock wave), dan terurainya tumpukan kendaraan saat lampu hijau mulai menyala (rarefaction wave). Selanjutnya skema juga digunakan untuk mensimulasikan bertambahnya kepadatan lalu lintas akibat penyempitan ruas jalan, serta akibat penutupan jalan.
\end{abstract}

Kata Kunci: persamaan Kinematic LWR, shock wave, rarefaction wave, metode finite volume

\section{Pendahuluan}

$\mathbf{K}$ EMACETAN lalu lintas merupakan permasalahan yang sering terjadi di kota-kota besar. Misalnya salah satu penyebab adalah adanya penyempitan ruas jalan yang menyebabkan kepadatan kendaraan pada arus lalu lintas. Penyempitan tersebut terjadi karena adanya galian dan perbaikan jalan atau dari ukuran kapasitas jalan yang menjadi kecil dan berbagai kasus lalu lintas lainnya. Permasalahan inilah yang mendasari simulasi pada penelitian ini.

Salah satu contoh misalnya pada Gambar 1, terdapat penyempitan pada ruas jalan yang mengakibatkan menumpuknya kendaraan di suatu tempat tertentu sehingga kapasitas pada jalan tersebut menjadi setengah dari kapasitas maksimum. Sehingga hal ini membuat jalanan menjadi terhambat lalu mengakibatkan kecepatan pada kendaraan mengalami perlambatan. Bila hal ini dibiarkan maka akan mengakibatkan kemacetan pada kendaraan lain yang berada dibelakangnya.

Oleh karena itu diperlukan suatu simulasi pemodelan matematika yang dapat menjadi solusi dari permasalahan tersebut. Sehingga diperoleh simulasi yang tepat untuk masalah penyempitan pada ruas jalan.

Received on Jul 2018. Accepted on Sept 2018 


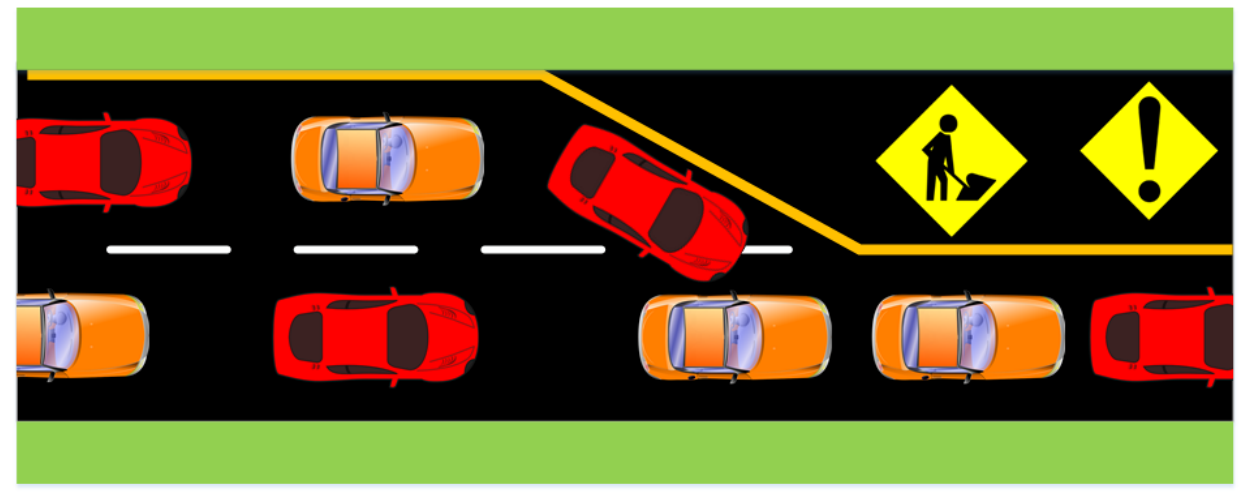

Gambar 1. Gambar penyempitan ruas jalan.

Adapun salah satu solusinya, dengan menemukan variasi model matematika yang sesuai dengan permasalahan yang ada di jalan raya. Beberapa ahli matematika telah melakukan penelitian dengan menggunakan banyak pendekatan teori, seperti: teori fundamental kalkulus, hukum konservasi integral, persamaan diferensial parsial, dan alternatif penurunan rumus lainnya untuk mendapatkan model penyelesaian masalah dalam bidang lalu lintas [10]. Contoh dari penelitian yang pernah dilakukan oleh beberapa ahli dapat dilihat pada referensi [1], [3]. Pada [2] model arus lalu lintas disimulasikan dengan skema konservatif upwind untuk memperlihatkan hasil numerik dengan solusi analitik dan tingkat kekonvergenan skema yang digunakan.

Pada dasarnya model lalu lintas dikelompokkan menjadi dua bagian, kedua bagian tersebut menjadi pembeda umum pengembangan simulasi dalam bidang ini. Pertama, pendekatan mikroskopik, model ini mencakup hubungan kendaraan dalam arus lalu lintas secara langsung, seperti hubungan antara satu kendaraan dengan kendaraan lain dalam suatu iringan kendaraan. Kedua, pendekatan makroskopik, merupakan pengamatan kondisi lalu lintas dalam cakupan luas, seperti bagaimana pola iringan kendaraan dalam suatu kondisi jalan raya dan pengaruh komponen lalu lintas yang lain (lihat referensi [4]-[8], [11]). Dalam penulisan jurnal ini penulis mengangkat topik mengenai pendekatan makroskopik dalam model arus lalu lintas, yakni simulasi berbagai masalah arus lalu lintas. Pada jurnal ini menggunakan metode yang sesuai untuk kemacetan pada lalu lintas. Metode finite volume merupakan metode yang pas untuk jurnal ini, karena metode ini dapat menyimulasikan berbagai macam situasi arus lalu lintas di jalan raya. Pembuatan simulasi ini bertujuan untuk memetakan pengaruh dari jumlah kendaraan yang berada pada badan jalan terhadap kecepatan pergerakan kendaraan yang ada dibelakang untuk melintasi jalanan.

Ada beberapa permasalahan yang ingin penulis angkat yaitu, bagaimana cara memodelkan skema numerik untuk persamaan transport kinematik Lightill, Whitman, dan Richard (LWR) dalam masalah arus lalu lintas dengan menggunakan metode finite volume, dan bagaimana menerapkan metode finite volume kedalam berbagai kasus simulasi pada model arus lalu lintas serta pengaruh berbagai kasus simulasi pada model arus lalu lintas terhadap kepadatan kendaraan menggunakan metode finite volume.

Permasalahan yang akan dibahas dalam jurnal ini dibatasi dengan beberapa hal, yaitu jalur hanya diberlakukan satu arah dan simulasi ini berlaku untuk kendaraan roda empat.

Tujuan yang ingin dicapai pada penulisan jurnal yaitu mengetahui model skema numerik dari persamaan transport dalam masalah arus lalu lintas dan menerapkan metode finite volume kedalam berbagai kasus pada masalah arus lalu lintas serta untuk mengetahui pengaruh berbagai kasus simulasi pada model arus lalu lintas terhadap kepadatan kendaraan menggunakan metode finite volume. 


\section{STUdi TERKAIT}

\section{A. Model Arus Lalu Lintas}

Arus lalu lintas adalah suatu gerakan pengemudi dengan kendaraan dari suatu tempat tertentu melintasi jalan raya menuju tempat tujuan. Sayangnya, mempelajari arus lalu lintas sulit karena perilaku pengemudi adalah sesuatu yang tidak dapat diprediksi dengan pasti. Untungnya, pengemudi cenderung berperilaku dalam kisaran cukup konsisten, dengan demikian aliran lalu lintas cenderung memiliki beberapa konsistensi yang wajar dan dapat dimodelkan melalui persamaan matematika.

Model arus lalu lintas adalah representasi ilmu matematika yang meliputi teori, proses dan sistem dalam lalu lintas. Model arus lalu lintas terus dikembangkan untuk meningkatkan kemampuan dalam mengerti, mengontrol dan memprediksi sistem lalu lintas yang teliti supaya dapat menjawab dan mengatasi kendala lain untuk meningkatkan keamanan dalam berkendara dijalan raya [5]. Arus lalu lintas di jalan raya terdiri dari beberapa jenis kendaraan yang bergerak dari suatu tempat tertentu melintasi jalan raya dengan kecepatan berbeda menuju tempat tujuan, ketika beberapa kendaraan bergerak melintasi jalan raya dalam waktu yang sama menyebabkan perubahan densitas kendaraan dari yang sebelumnya kosong akan bertambah membentuk iringan kendaraan hingga mencapai nilai maksimum kapasitas jalan raya [3]. Terdapat dua pendekatan yang banyak digunakan untuk mengkaji aliran lalu lintas, yaitu: pendekatan makroskopik dan pendekatan mikroskopik.

Pendekatan mikroskopik digunakan untuk menganalisa kondisi atau keadaan lalu lintas dengan ruang pengamatan yang relatif sempit, dan menggambarkan perilaku kendaraan secara langsung terhadap pengendara lain, seperti sikap suatu kendaraan dengan kendaraan lain ketika terjadi perpindahan jalur dijalan raya.

Sedangkan pendekatan makroskopik biasanya diterapkan untuk ruang lingkup kajian yang relatif luas. Pengamatan lalu lintas pada pendekatan ini tidak memperhitungkan mobil-mobil secara individu melainkan hanya memperhitungkan kepadatannya saja. Model ini merupakan sistem kesatuan antara: kondisi lalu lintas, kecepatan, dan densitas dalam suatu interval waktu yang membentuk aliran lalu lintas dalam setiap aspek secara keseluruhan [10].

\section{B. Persamaan Kinematik Lightill, Whitman, dan Richard (LWR)}

Pada jurnal ini menggunakan pendekatan makroskopik dengan variabel kepadatan kendaraan (mobil/km), dinotasikan sebagai $n(x, t)$, dan fluks kendaraan (mobil/jam) dinotasikan sebagai $f(n(x, t))$. Perhatikan persamaan kinematik Lightill, Whitman, dan Richard (LWR) sebagai berikut:

$$
n_{t}+f(n)_{x}=0
$$

Persamaan kinematik LWR adalah persamaan yang mengkaitkan perubahan densitas kendaraan dengan fluks atau arus dalam sebuah pengamatan. Pada sub-bab selanjutnya akan dibahas model pada fungsi arus tersebut.

\section{Model Greenshield}

Model Greenshield adalah salah satu model yang paling sederhana karena dengan menggunakan model ini dapat menangkap dua karakteristik utama dalam fenomena lalu lintas yaitu: kecepatan terhadap kepadatan kendaraan dan arus/fluks lalu lintas terhadap kepadatan kendaraan. Diasumsikan kecepatan rata-rata dan kerapatan lalu lintas berhubungan linear. Hubungan ini dinyatakan secara matematis dan grafis sehingga:

$$
v(n)=v_{\max }\left(1-\frac{n}{n_{\max }}\right),
$$

dengan $v_{\max }(\mathrm{km} / \mathrm{jam})$ menunjukkan kecepatan maksimum kendaraan di jalanan yang kosong, dan $n_{\text {max }}($ mobil $/ \mathrm{km})$ menyatakan kapasitas maksimum pada lajur lalu lintas, lihat Gambar 2.

Selanjutnya, Kerapatan lalu lintas dan arus arus lalu lintas berhubungan dengan $f=n v$, dengan $v$ menyatakan kecepatan rata-rata kendaraan. Sehingga arus lalu lintas menjadi: 


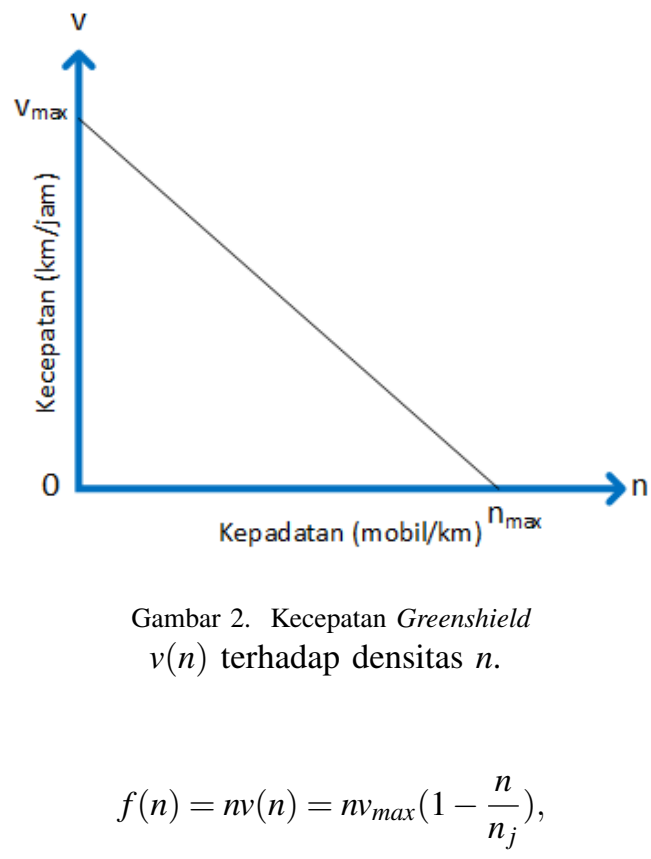

Model Greenshield dapat menangkap dua fenomena arus lalu lintas yaitu: arus lalu lintas kosong apabila kepadatan kendaraan nol $(\mathrm{n}=0)$ atau maksimum ketika $\left(n=n_{\max }\right)$ dan arus lalu lintas menjadi maksimum apabila $n \approx \frac{n_{\max }}{2}$, lihat Gambar 3 .

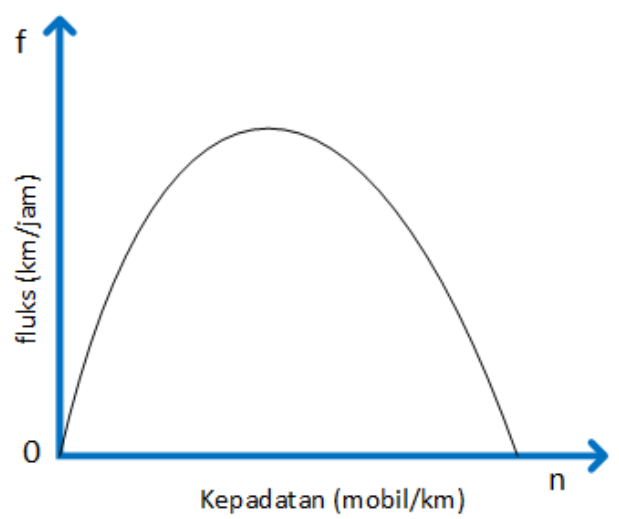

Gambar 3. Arus lalu lintas $\mathrm{f}(\mathrm{n})$ terhadap kepadatan $\mathrm{n}$ greenshield.

\section{Metode Finite Volume}

Berawal dari persamaan konservasi dengan fungsi fluks $f(u)$ untuk kondisi awal seperti berikut ini:

$$
\begin{gathered}
u_{t}+f(u)_{x}=0, \quad x \in \mathbb{R}, \quad t>0 . \\
u(x, 0)=u(x), \quad x \in \mathbb{R} .
\end{gathered}
$$

Secara umum $f(u)$ adalah fungsi non-linier dari $u$ [9]. Disini akan dibahas metode finite volume dari kasus yang paling sederhana pada domain $[0, L]$ yang dibagi menjadi sel $N_{x}$ sepanjang $\Delta x$, dengan titik partisinya adalah:

$$
x_{1 / 2}=0, x_{3 / 2}=\Delta x, \ldots, x_{i+1 / 2}=i \Delta x, \ldots, x_{N x+1 / 2}=N_{x} \Delta x=L
$$




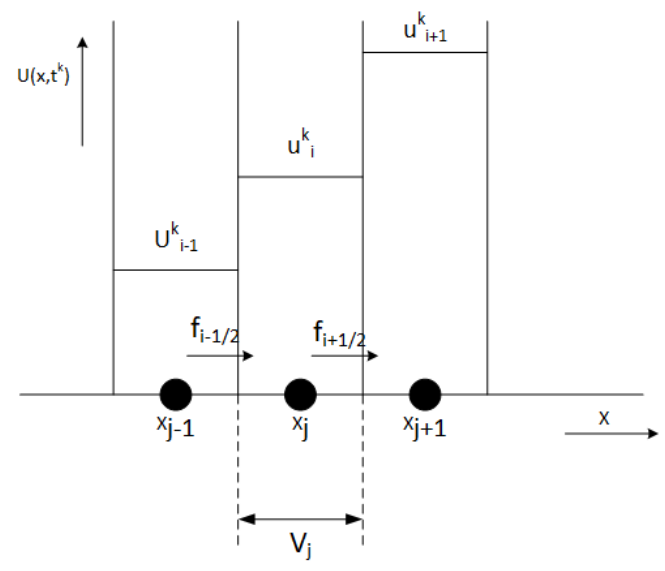

Gambar 4. Skema finite volume dengan ilustrasi stensil.

Diasumsikan bahwa $u\left(x_{i}, t^{k}\right)$ menunjukkan nilai rata-rata $u$ dalam sel $V_{j}=\left[x_{i-1 / 2}, x_{i+1 / 2}\right]$, Kita formulasikan bentuk diskrit persamaan (4) sebagai berikut:

$$
u_{i}^{k+1}=u_{i}^{k}-\frac{\Delta t}{\Delta x}\left(f_{i+\frac{1}{2}}^{k}-f_{i-\frac{1}{2}}^{k}\right)
$$

Perhatikan Gambar 4, yang mengilustrasikan perubahan nilai $u_{i}^{k}$ pada setiap langkah $t^{k}$ menggunakan persamaan (7). Nilai $u_{i}$ diperbaharui dengan menggunakan fluks dari batas kiri dan kanan. Yang perlu kita lakukan hanyalah merumuskan skema aproksimasi yang baik untuk fluks $f\left(x_{i+1 / 2}, t^{k}\right)$, yang merupakan unsur terpenting dari metode finite volume. Digunakan notasi $U_{i}^{k}=u\left(x_{i}, t^{k}\right)$, dan $f_{i}^{k}=f\left(x_{i-1 / 2}, t^{k}\right)$, untuk semua $x_{i-1 / 2}$ pada domain waktu saat $t^{k}$.

Seringkali fungsi fluks bergantung pada $u$, jadi percobaan pertama bisa digunakan rata-rata untuk menghampiri:

$$
f_{i+1 / 2}^{k}=\frac{1}{2}\left(f\left(u_{i}^{k}+f\left(u_{i+1}^{k}\right)\right)\right.
$$

Jika menggunakan hampiran (8) di atas maka metode finite volume (7) menjadi:

$$
u_{i}^{k+1}=u_{i}^{k}-\frac{\Delta t}{2 \Delta x}\left(f\left(u_{i+1}^{k}-f\left(u_{i-1}^{k}\right)\right)\right.
$$

Pada bab selanjutnya akan dibahas mengenai metode finite volume untuk menyelesaikan model kinematik LWR dengan fungsi fluks Greenshield (3).

\section{Sistem YANG DibANGUN}

\section{A. Skema Numerik Persamaan Kinematik LWR Menggunakan Metode finite volume dengan upwind}

Perhatikan domain komputasi $[0, L]$, selanjutnya domain komputasi dibagi menjadi $M$ sel dengan panjang $\Delta x$. Untuk titik partisinya dimulai dari $x_{\frac{1}{2}}=0, x_{\frac{3}{2}}=\Delta x, \ldots, x_{i+\frac{1}{2}}=i \Delta x, \ldots, x_{M+\frac{1}{2}}=M \Delta x=x$. Pada cell $v_{i}=\left[x_{i-\frac{1}{2}}, x_{i+\frac{1}{2}}\right.$, kita formulasikan bentuk diskrit persamaan kinematik LWR (1) sebagai berikut:

$$
n_{i}^{k+1}=n_{i}^{k}-\frac{\Delta t}{\Delta x}\left(f_{i+\frac{1}{2}}^{k}-f_{i-\frac{1}{2}}^{k}\right)
$$

Seperti pada Gambar 4 sebelumnya, yaitu mengilustrasikan perubahan nilai $n_{i}^{k}$ pada setiap langkah $t_{k}$ menggunakan persamaan (10). Nilai $n_{i}$ diperbaharui dengan menggunakan fluks dari batas kiri dan kanan. Untuk fluksnya sendiri $\left(f_{i+\frac{1}{2}}^{k}\right)$ dihampiri dengan menggunakan pendekatan upwind. Nilai $\left(f_{i+\frac{1}{2}}^{k}\right)$ 
dihmapiri dengan $\left(f_{i}^{k}\right)$ jika fluks positif dan dihampiri dengan $\left(f_{i+1}^{k}\right)$ jika fluks negatif. Selanjutnya arah fluks dititik $x_{k+\frac{1}{2}}$ didekati oleh $\frac{1}{2}\left(f_{i}^{\prime}+f_{i+1}^{\prime}\right)$ sehingga diperoleh:

$$
f_{i+\frac{1}{2}}^{k} \approx\left\{\begin{array}{l}
f_{i}^{k}, \quad \text { jika } \quad \frac{1}{2}\left(f_{i}^{\prime}+f_{i+1}^{\prime}\right)>0 \\
f_{i+1}^{k}, \quad \text { jika } \quad \frac{1}{2}\left(f_{i}^{\prime}+f_{i+1}^{\prime}\right) \leq 0
\end{array}\right.
$$

Pendekatan dengan menggunakan skema upwind di atas (11) menyatakan apabila arah kecepatan positif maka $f_{i+\frac{1}{2}}^{k} \approx f_{i}^{k}=n_{i}^{k} v_{f}\left(1-n_{i}^{k} / n_{j}\right)$, namun jika arahnya negatif $f_{i+\frac{1}{2}}^{k} \approx f_{i+1}^{k}=n_{i+1}^{k} v_{f}\left(1-n_{i+1}^{k} / n_{j}\right)$.

1) Algoritma Metode Finite Volume dengan upwind: Selanjutnya pada sub-bab ini diuraikan urutan langkah-langkah yang diperlukan dalam penerapan metode finite volume. Adapun langkah-langkah dalam penggunaan metode ini yaitu langkah pertama, menentukan langkah spasial pada fungsi $\Delta x$ yang didapat dari hasil bagi panjang domain terhadap jumlah titik grid yang ingin dibentuk pada plot. Langkah selanjutnya, menetapkan nilai vektor $n$ dan nilai awal dari vektor $n_{L}$ dan $n_{R}$ untuk kondisi awal, kemudian dilakukan pengaturan waktu dalam pemrosesan program. Langkah berikutnya, mencari nilai $f(n)$ yang didapat dari penurunan fungsi awal dan pengolahan data untuk mendapatkan bentuk diskrit dengan menggunakan metode upwind. Selanjutnya, menentukan nilai boundary condition atau batasan kondisi, dan memperbaharui nilai $n$ untuk perulangan selanjutnya. Tahap terakhir, maka dibentuk plot dari hasil perhitungan. Dalam bentuk algoritma, dapat dilihat pada Algoritma 1 berikut:

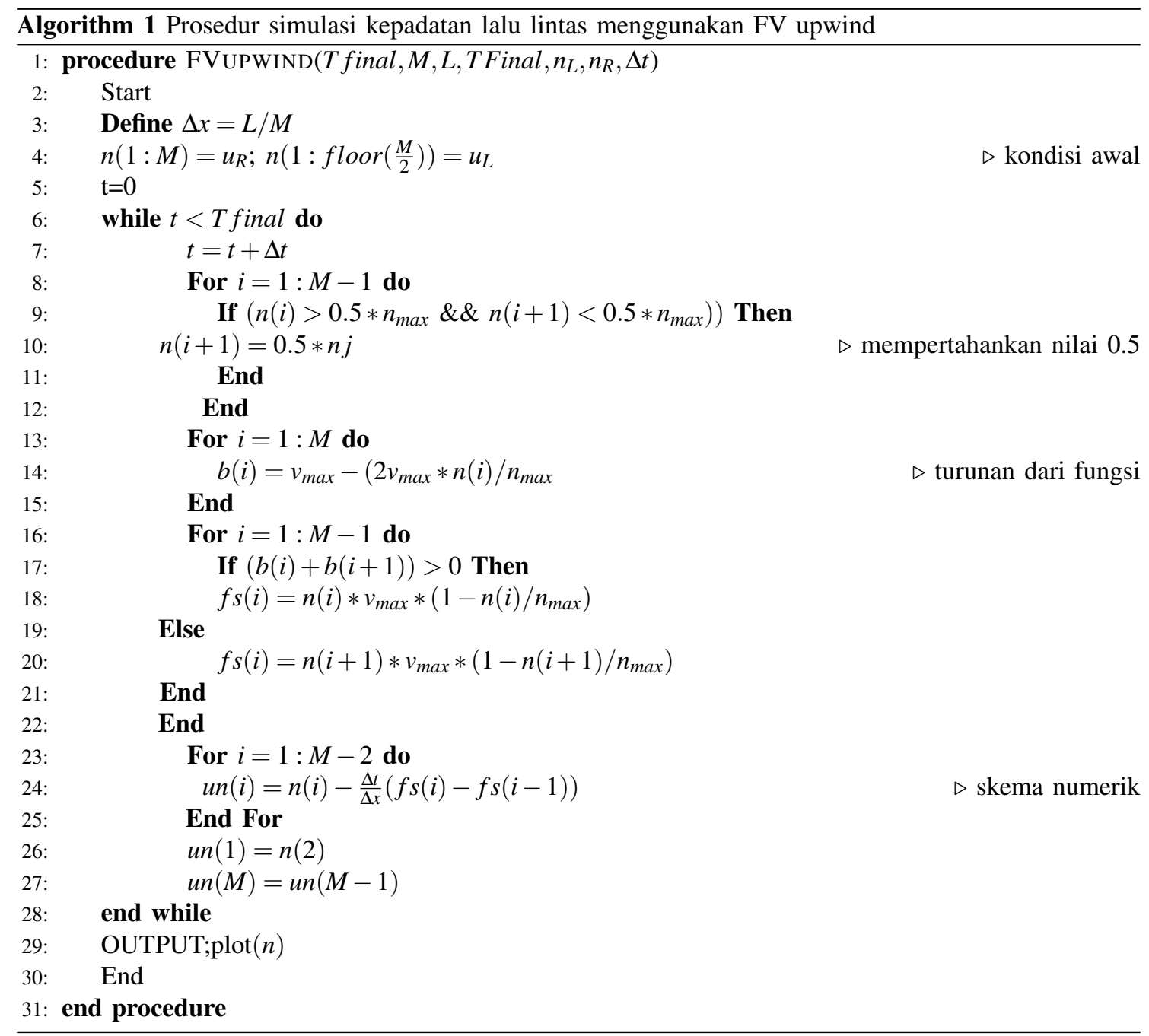




\section{B. Solusi Shock wave dan Rarefaction wave}

Berawal dari model kinematik LWR dengan fungsi fluks Greenshield (2) pada sub-bab sebelumnya dengan kondisi awal seperti berikut:

$$
n(x, 0)=\left\{\begin{array}{lll}
n_{L}, & \text { jika } & x \leq 0 \\
n_{R}, & \text { jika } & x>0
\end{array}\right.
$$

- $\operatorname{kasus} n_{L}<n_{R}$.

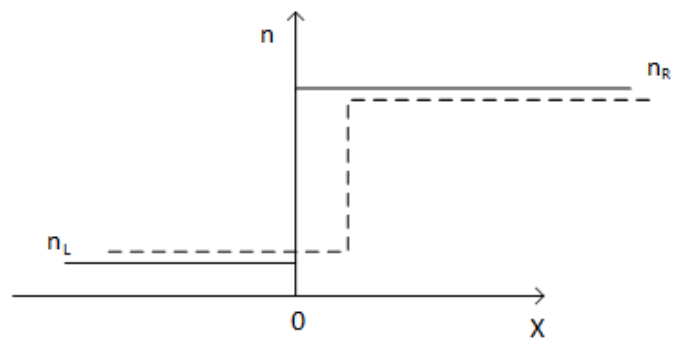

Gambar 5. Ilustrasi densitas pada kondisi $n_{L}<n_{R}$.

Apabila nilai $n_{L}$ lebih kecil dari nilai $n_{R}$ dan terdapat garis karakteristik yang saling berpotongan maka kasus tersebut disebut solusi shockwave. Lihat Gambar 6.
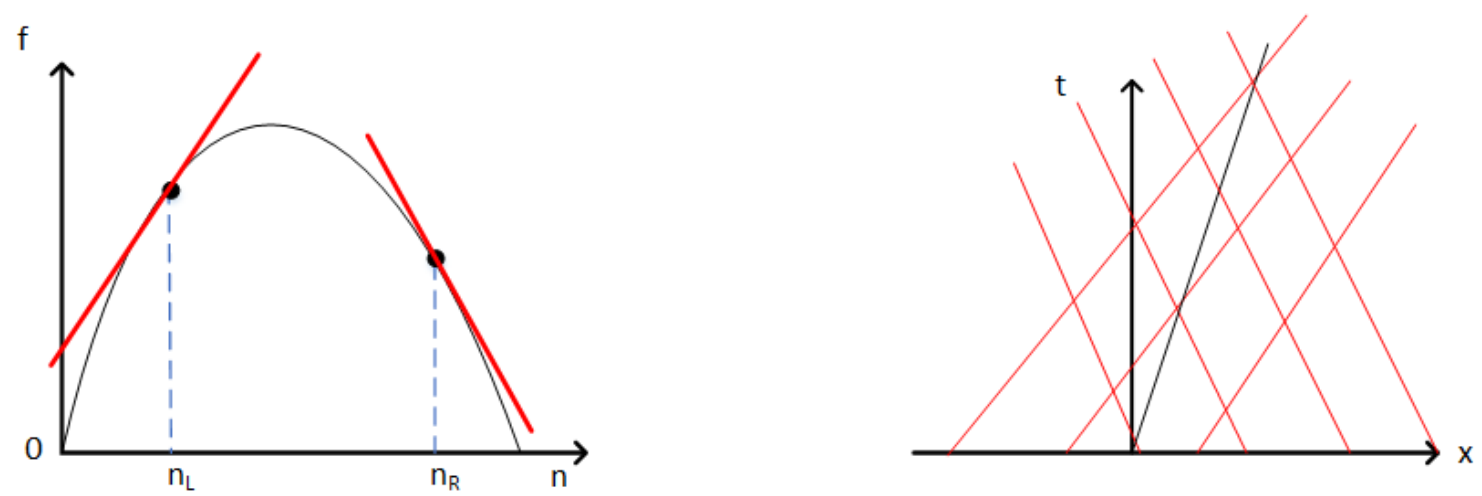

Gambar 6. Ilustrasi $f^{\prime}\left(n_{L}\right) \& f^{\prime}\left(n_{R}\right)$ (kiri) dan garis karakteristik (kanan) jika pada kondisi $n_{L}<n_{R}$.

- $\operatorname{kasus} n_{L}>n_{R}$.

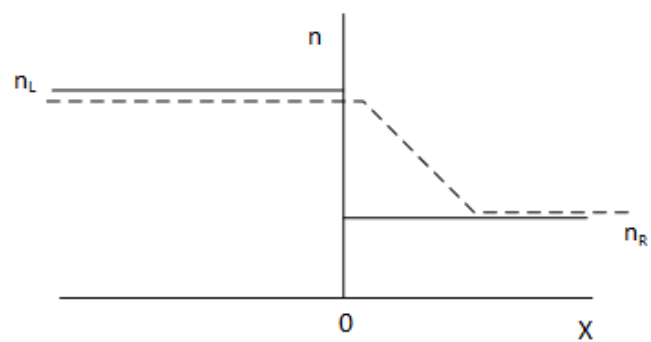

Gambar 7. Ilustrasi densitas pada kondisi $n_{L}>n_{R}$.

Sedangkan apabila nilai $n_{L}$ lebih besar dari nilai $n_{R}$ dan memiliki garis karakteristik yang tidak saling berpotongan maka kasus ini disebut solusi rarefaction wave, lihat Gambar 8 untuk lebih detail. 

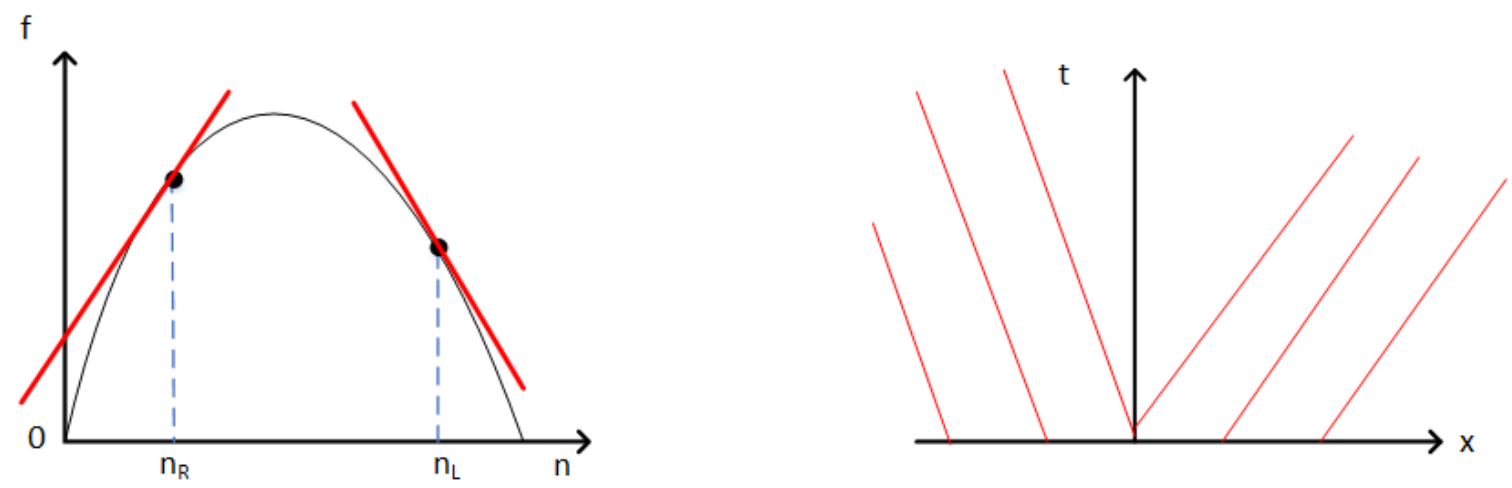

Gambar 8. Ilustrasi $f^{\prime}\left(n_{L}\right) \& f^{\prime}\left(n_{R}\right)$ (kiri) dan garis karakteristik (kanan) jika pada kondisi $n_{L}>n_{R}$.

\section{Pembahasan dan Evaluasi}

Dilakukan simulasi berbagai situasi lalu lintas menggunakan persamaan kinematik LWR (1) dan fungsi fluks Greenshield (2) dengan metode finite volume.

\section{A. Simulasi shock wave dan rarefaction wave}

Pada sub-bab ini akan dilakukan simulasi untuk solusi shock wave dan rarefaction wave pada model arus lalu lintas.

1) Simulasi shock wave: Misalkan kita lagi berada di jalan raya mengendarai sebuah mobil menuju ke suatu tempat, lalu beberapa saat kemudian kita melihat tepat di depan adanya kepadatan kendaraan karena penumpukan yang menyebabkan antrian pada kendaraan, akan dilakukan simulasi terhadap fenomena tersebut. Berawal dari persamaan kinematik LWR (1) dengan kondisi awal sebagai berikut:

$$
n(x, 0)=\left\{\begin{array}{ccc}
n_{L}, & \text { jika } & x \leq 0 \\
n_{R}, & \text { jika } & x>0
\end{array}\right.
$$

Solusi shock wave terjadi apabila $n_{L}<n_{R}$, artinya kita bisa memisalkan keadaan $n_{L}$ yaitu kepadatan yang relatif rendah dan $n_{R}$ sebagai kepadatan yang relatif lebih tinggi, dengan menggunakan fungsi fluks Greenshield (2) didapatkan solusi numerik seperti berikut, lihat Gambar 9. Atau dalam bentuk animasi dapat dilihat seperti pada Gambar 10.
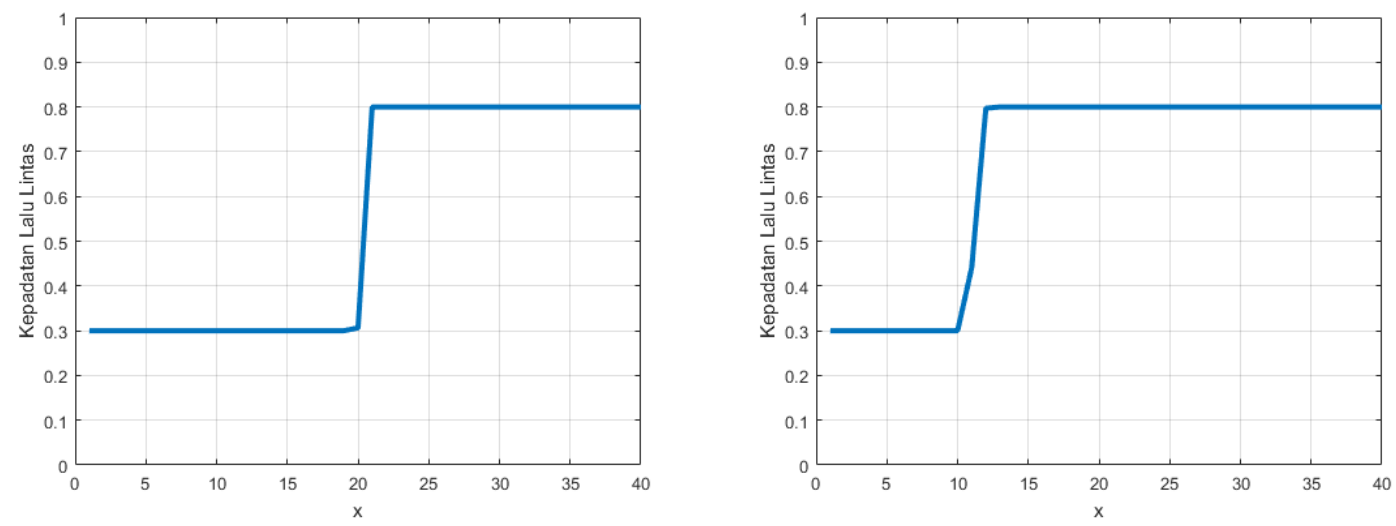

Gambar 9. Simulasi shock wave: (kiri) saat $t$ awal, dan (kanan) saat $t$ berikutnya. 

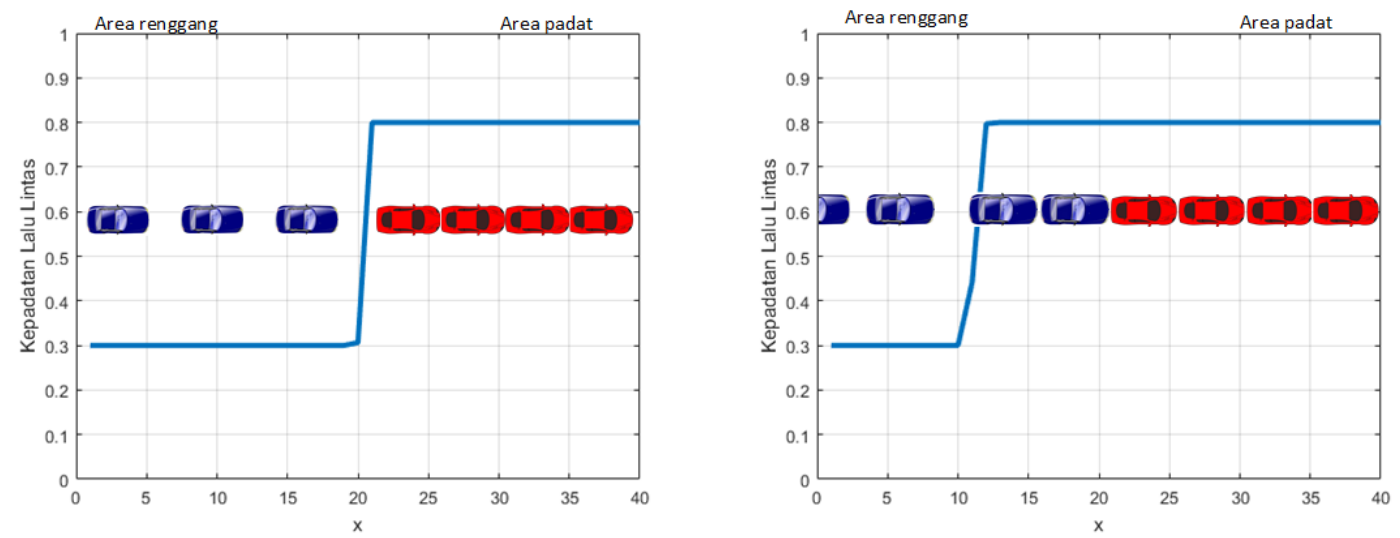

Gambar 10. Simulasi shock wave: (kiri) saat $t$ awal, dan (kanan) saat $t$ berikutnya.

Saat $t$ awal mobil biru belum memasuki area padat, selang beberapa waktu berikutnya mobil biru mulai memasuki area padat kendaraan.

2) Simulasi rarefaction wave: Pada kasus selanjutnya misalkan kita berada pada antrian untuk menunggu perubahan lampu lalu lintas dari merah menjadi hijau, kita bisa melihat perubahan kepadatan kendaraan yang terurai dari yang awal padat kendaraan menjadi berkurang. Situasi ini ini akan disimulasikan, Berawal dari persamaan kinematik LWR (1) dengan kondisi awal sebagai berikut:

$$
n(x, 0)=\left\{\begin{array}{lll}
n_{L}, & \text { jika } & x \leq 0 \\
n_{R}, & \text { jika } & x>0
\end{array}\right.
$$

Solusi rarefaction wave terjadi apabila $n_{L}>n_{R}$, artinya kita bisa memisalkan keadaan $n_{L}$ yaitu kepadatan yang relatif tinggi atau maksimum dan $n_{R}$ sebagai kepadatan yang kosong karena tidak adanya kendaraan yang lewat, dengan menggunakan fungsi fluks Greenshield (2) didapatkan solusi numerik seperti pada Gambar 11.

Pada Gambar 11, saat kondisi awal kepadatan tinggi $\left(n_{L}\right)$ mencapai maksimum, selanjutnya terjadi perubahan densitas kendaraan karena lampu lalu lintas berubah menjadi hijau yang mana kepadatan menjadi terurai dan membuat pengendara memacu kendaraannya.

\section{B. Kasus Penyempitan Jalan}

Pada kasus berikutnya dilakukan simulasi dari persamaan kinematik LWR untuk kasus penyempitan ruas lalu lintas jalan (lihat ilustrasi seperti pada Gambar 1).

Misal Gambar 1 menunjukkan suatu jalan yang terisi padat kendaraan dari kapasitas maksimum jalan. Selanjutnya terjadi penyempitan pada ruas jalan yang mengakibatkan kapasitas maksimum pada jalan tersebut menjadi setengahnya dan membuat kendaraan menumpuk. Penumpukan kendaraan berawal dari lokasi penyempitan jalan yang mana kemudian merambat kebelakang. Efek penumpukan kendaraan ini bisa merambat terus hingga jauh kebelakang dan mengakibatkan kemacetan pada kendaraan yang berada dibelakangnya. Untuk algoritmanya sendiri ada sedikit modifikasi pada fungsi fluks $f(n(x, t))$.

Selanjutnya situasi ini akan disimulasikan, misalkan saat awal kondisi jalan stabil yang dapat ditulis seperti berikut ini:

$$
n(x, 0)=0.6 \quad x \in \mathbb{R}
$$

Selanjutnya, simulasi terjadinya kemacetan dimana 50\% kendaraan tidak dapat masuk pada $x=20$. Perhatikan ruas jalan sepanjang $L=40$, dan di $x=\frac{L}{2}$ terjadi penyempitan dimana kendaraan yang bisa lewat hanya setengahnya saja.

Domain komputasi $[0, \mathrm{~L}]$, penyempitan terjadi pada titik $x=20$, maksudnya adalah pada titik $x=21$ fungsi $f(n(20, t)$ diubah menjadi setengah dari kapasitas maksimum untuk membuat terjadinya kasus 

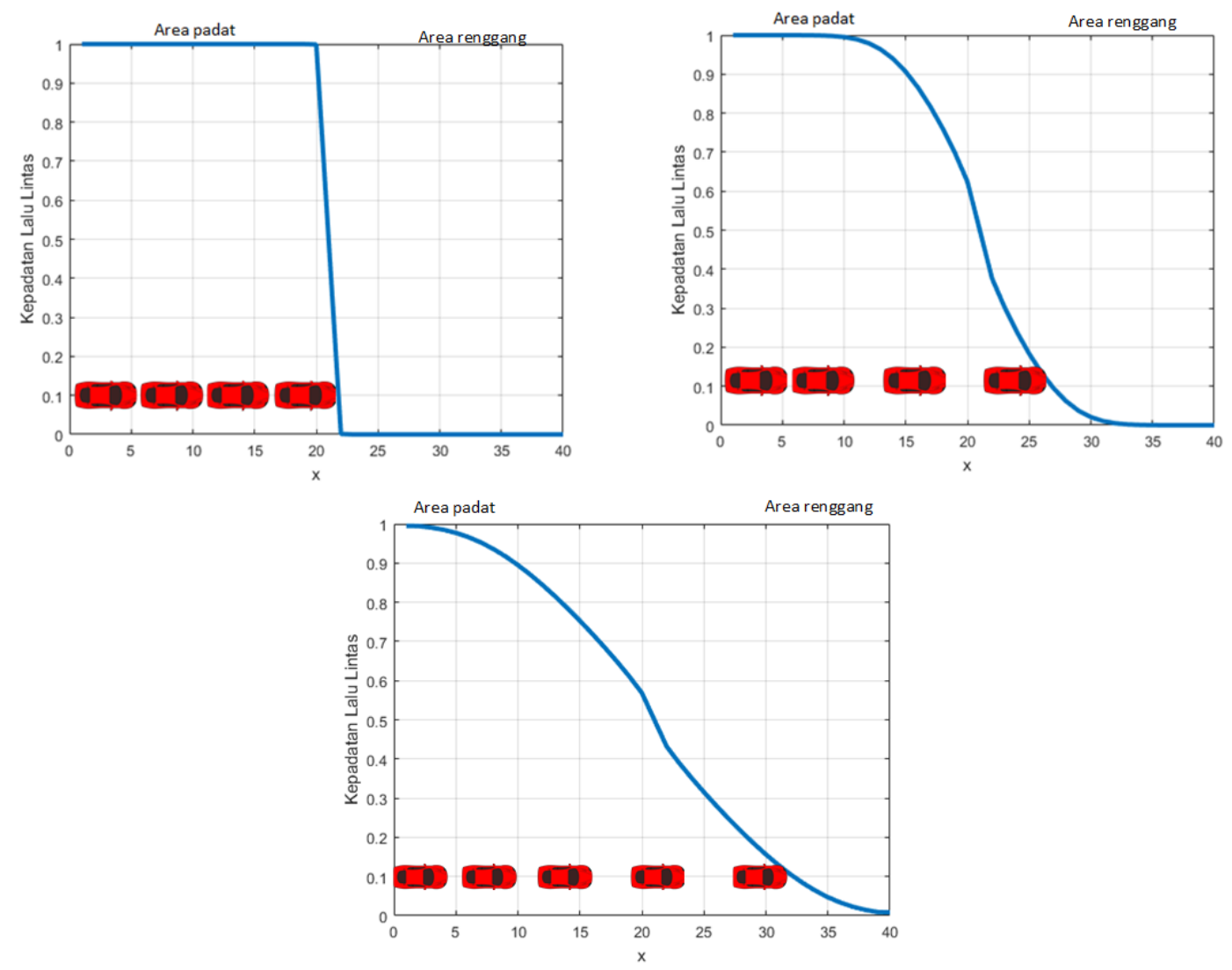

Gambar 11. Snapshoot kurva $n(x, t)$ untuk beberapa waktu pengamatan.

penyempitan. Dapat dilihat hasil simulasi pada Gambar 12(kanan).
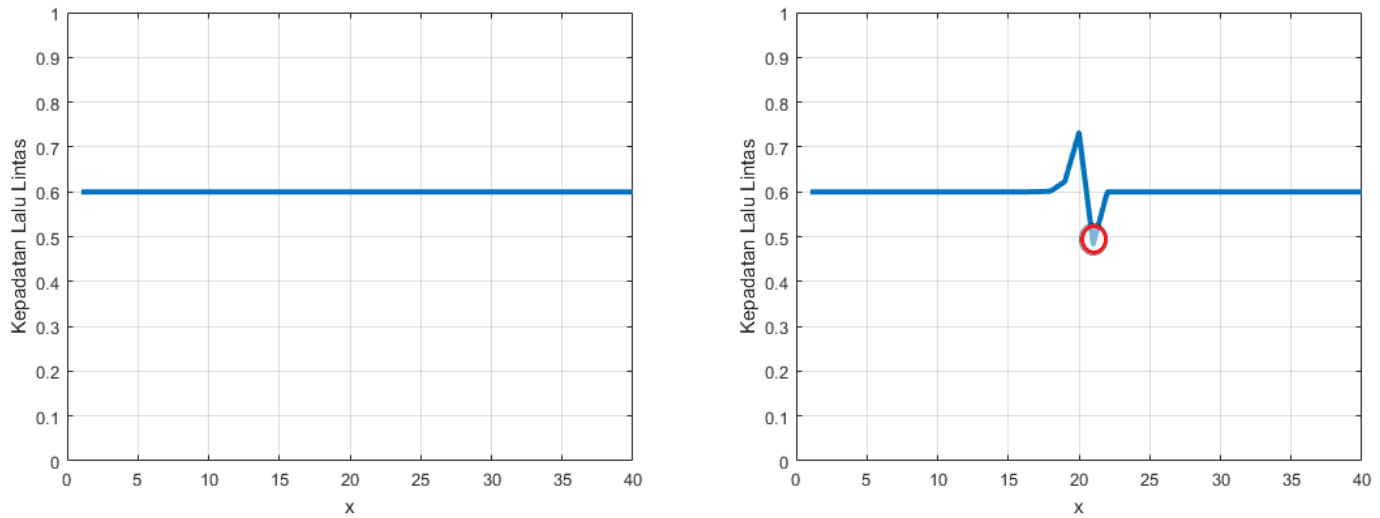

Gambar 12. Snapshoot kurva $n(x, t)$ untuk awal waktu pengamatan (kiri) dan saat terjadi penyempitan.

Gambar 12-13 merupakan saat terjadinya penyempitan pada ruas jalan. Berdasarkan Gambar 12, pada titik $\mathrm{x}=21$ terjadi penyempitan badan jalan sebesar setengah dari kapasitas maks suatu jalan. Lalu pada Gambar 13 (kiri), kepadatan mulai meningkat menjadi 80\%. Selanjutnya Gambar 13(kanan), kepadatan sudah merambat kebelakang. Selanjutnya akan disimulasikan kasus-kasus lain pada sub-bab berikutnya. 

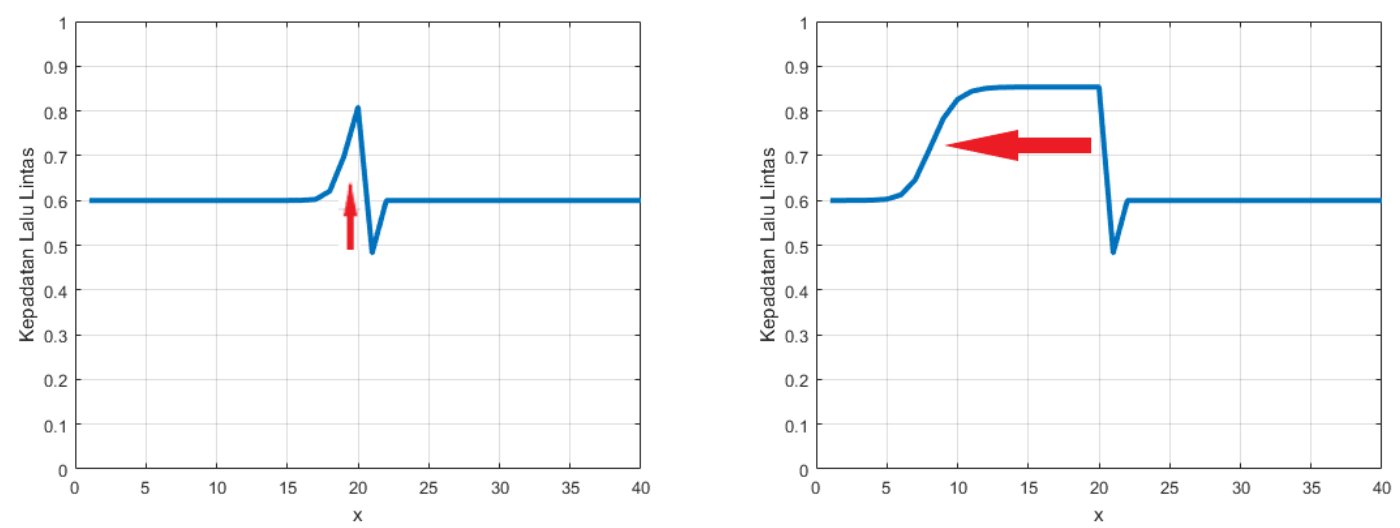

Gambar 13. Snapshoot kurva $n(x, t)$ untuk beberapa waktu pengamatan.

\section{Kasus Jalanan ditutup}

Pada kasus berikutnya dilakukan simulasi dari persamaan kinematik LWR untuk kasus jalanan ditutup (lihat ilustrasinya pada Gambar 14).

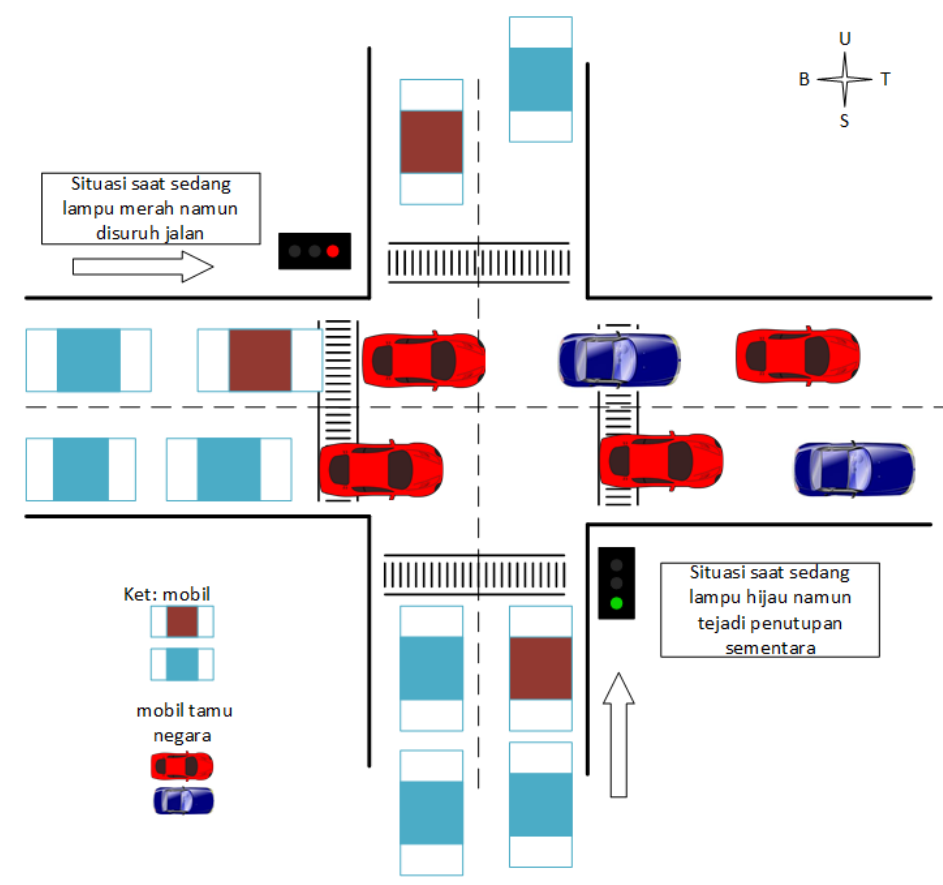

Gambar 14. Ilustrasi sebuah persimpangan jalan.

Misal di suatu perempatan jalan dari arah selatan menuju utara saat lampu sedang hijau tetapi dipaksa berhenti untuk sementara karena adanya tamu negara atau tamu penting yang melewati jalan dari arah barat menuju timur sehingga mengakibatkan jalan yang awalnya lampu hijau dipaksa untuk ditutup beberapa waktu sampai tamu-tamu negara tersebut melewati perempatan. Efeknya membuat kendaraan lain yang ada dibelakang dari jalan arah selatan menuju utara menumpuk. Selanjutnya situasi ini akan disimulasikan, misalkan saat awal kondisi jalan $60 \%$ padat atau secara matematis dapat ditulis sebagai berikut:

$$
u(x, 0)= \begin{cases}0.6, & \text { jika } x<0 \\ 0.6, & \text { jika } x>0\end{cases}
$$


Perhatikan ruas jalan sepanjang $L=40$, dan di $x=L / 2$ terjadi penutupan jalan sementara. Domain komputasi $[0, L]$, penutupan terjadi pada titik $x=21$. Maksudnya pada titik $x=21$ fungsi $f(n(21, t))$ nilainya diubah menjadi nol. Dapat dilihat hasil simulasi ini pada Gambar 15.
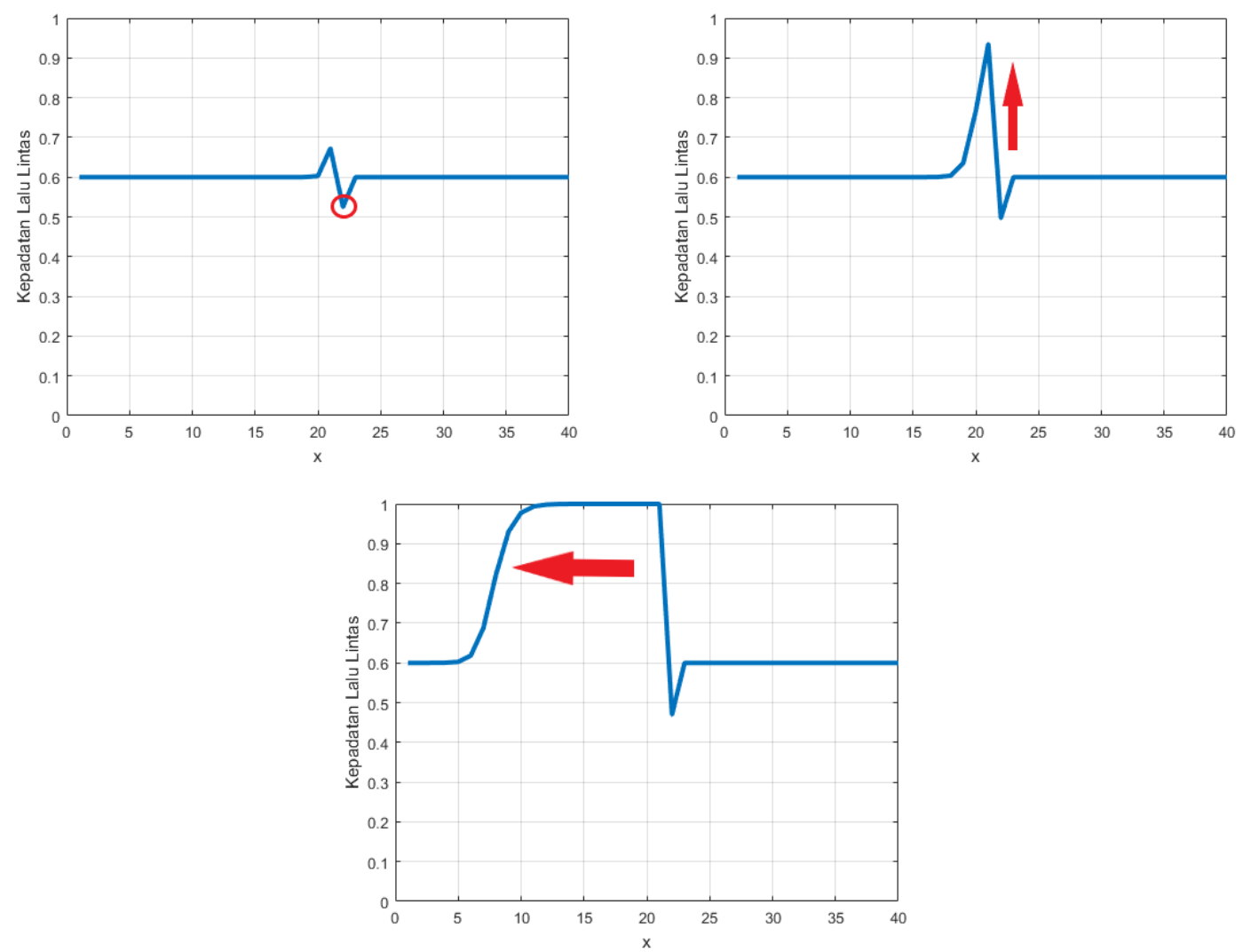

Gambar 15. Hasil simulasi penutupan jalan di persimpangan jalan.

Gambar 15 merupakan saat terjadinya penutupan pada ruas jalan. Berdasarkan Gambar 15 (kiri atas) pada titik $x=21$ terjadi penutupan pada jalan karena adanya tamu kenegaraan yang ingin melewati perempatan tersebut, lalu pada Gambar 15(kanan atas) kepadatan mulai meningkat menjadi 100\% karena semua kendaraan berhenti. Selanjutnya Gambar 15(bawah) kepadatan sudah merambat kebelakang sehingga terjadi kemacetan.

\section{KESIMPULAN}

Metode finite volume dengan upwind telah berhasil diterapkan untuk melakukan simulasi aliran lalu lintas di berbagai kondisi. Metode ini relatif sederhana, dan dapat mempresentasikan berbagai situasi kemacetan lalu lintas di jalan raya. Metode finite volume telah berhasil menyimulasikan kasus lalu lintas jalan raya seperti bertambahnya panjang antrian kendaraan (shock wave), dan terurainya tumpukan kendaraan saat lampu hijau mulai menyala (rarefaction wave), bertambahnya kepadatan lalu lintas akibat penyempitan ruas jalan, serta akibat penutupan jalan adapun hasilnya sesuai seperti yang sering kita lihat seharihari. Adapun saran dari penulis. Karena keterbatasan data, penulis menyadari jurnal ini masih dapat dikembangkan. Oleh karena itu saran untuk pembaca agar dapat mengembangkan penelitian ini dengan menggunakan fungsi fluks yang lain dan data lapangan agar mendapatkan hasil yang lebih relevan. 


\section{UCAPAN TERIMA KASIH}

Penulis mengucapkan terima kasih banyak kepada Prof. Dr. Sri Redjeki Pudjaprasetya yang sudah membimbing dan memberi arahan sehingga jurnal ini dapat terselesaikan dengan baik.

\section{PUSTAKA}

[1] Chandramouli Gnanasambandham. littleindian: What does traffic-bottlenecks have to do with the continuity equation?

[2] PUTU HARRY Gunawan. The conservative upwind scheme for simple traffic flow model. In Prosiding Seminar Nasional Matematika 2014 of Udayana University Denpasar, volume 67, 2014.

[3] Richard Haberman. Mathematical models: mechanical vibrations, population dynamics, and traffic flow. SIAM, 1998.

[4] Walter Helly. Simulation of bottlenecks in single-lane traffic flow. 1900.

[5] SP Hoogendoorn and Victor Knoop. Traffic flow theory and modelling. Edward Elgar Publishing Limited, 2012.

[6] Michael J Lighthill and Gerald Beresford Whitham. On kinematic waves. ii. a theory of traffic flow on long crowded roads. Proceedings of the Royal Society of London. Series A, Mathematical and Physical Sciences, pages 317-345, 1955.

[7] Adolf D May. Traffic flow fundamentals. 1990.

[8] Markos Papageorgiou. Some remarks on macroscopic traffic flow modelling. Transportation Research Part A: Policy and Practice, 32(5):323-329, 1998.

[9] Sri Redjeki Pudjaprasetya. Lecture notes on numerical schemes for flow and transport problems. 2017.

[10] Ali R Soheili, Asghar Kerayechian, Hamed R Tareghian, and Noshin Davoodi. Adaptive numerical simulation of traffic flow density. Computers \& Mathematics with Applications, 66(3):227-237, 2013.

[11] GCK Wong and SC Wong. A multi-class traffic flow model-an extension of lwr model with heterogeneous drivers. Transportation Research Part A: Policy and Practice, 36(9):827-841, 2002. 
